\title{
Association of Bacterial Vaginosis and Skin Disorders in Patients with Autoimmune Antibody Positivity
}

\author{
Burcu BEKSAC', Hanife Guler DONMEZ² \\ Ankara, Turkey
}

\section{ABSTRACT}

OBJECTIVE: To investigate the association of bacterial vaginosis and skin disorders in patients with autoimmune antibody positivity.

STUDY DESIGN: This retrospective study consisted of 80 patients with autoimmune antibody positivity. All patients were evaluated for the presence of bacterial vaginosis and skin disorders. Cervicovaginal smears were used for the definitive diagnosis of bacterial vaginosis.

RESULT: We found bacterial vaginosis in $13.75 \%(11 / 80)$ of the cases. $1(9.1 \%)$ and $10(90.9 \%)$ cases had skin disorders in bacterial vaginosis positive and negative groups respectively $(p=0.531)$.

CONCLUSION: There is no relationship between bacterial vaginosis and the presence of skin disorders in patients with autoimmune antibody positivity.

Keywords: Autoimmune antibody positivity, Bacterial vaginosis, Skin disorders

Gynecol Obstet Reprod Med 2021;27(2):150-153

\section{Introduction}

Bacterial vaginosis (BV) is the most common cause of vaginal infection among fertile women with a prevalence that differs widely among different populations between 8 to $75 \%$ (1). In Turkey, the prevalence of BV changes between $7.2-23 \%(2,3)$. BV is especially important for an increased risk of late miscarriage, preterm labor, fetal growth retardation, chorioamnionitis, postpartum endometritis, and pelvic inflammatory disease (4). Predisposing factors that increase the risk of BV are multiple partners, vaginal douching, intrauterine device usage, and smoking (5). In our previous

${ }^{1}$ Department of Dermatovenereology, University of Health Sciences, Gulhane Training and Research Hospital, Ankara, Turkey

${ }^{2}$ Department of Biology, Faculty of Science, Hacettepe University, Ankara, Turkey

Address of Correspondence: Burcu Beksac

Department of Dermatology and

Venereology, Gulhane Research and

Training Hospital, Ankara,

burcubeksac@gmail.com

Submitted for Publication:14.05.2020 Revised for Publication:14.05.2020

Accepted for Publication: 19.05.2020 Online Published: 02.08.2021

ORCID IDs of the authors: BB: 0000-0001-5726-0696

HGD: 0000-0002-7413-4939

\begin{tabular}{|c|c|}
\hline \multirow{3}{*}{ 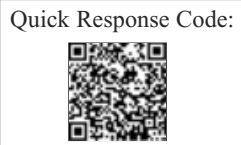 } & Access this article online \\
\hline & $\begin{array}{l}\text { Website: www.gorm.com.tr } \\
\text { e- mail: info@gorm.com.tr }\end{array}$ \\
\hline & DOI:10.21613/GORM.2020.1103 \\
\hline
\end{tabular}

How to cite this article: Beksac B. and Donmez HG. Association of Bacterial Vaginosis and Skin Disorders in Patients with Autoimmune Antibody Positivity. Gynecol Obstet Reprod Med 2021;27(2):150-153 study, BV was found to be more frequent in patients with AAP (6). BV affects vaginal mucosa and causes pruritus, irritation, and desquamation of the vulvar skin thus leading to a decrease in the quality of life (7).

The skin is composed of a multi-layered structure that forms a physical barrier protecting the body from environmental factors. Various types of skin disorders can be caused by autoimmune disorders, other immunologic discrepancies such as allergies, metabolic syndrome, and bacterial or viral infections (8-10). The immune system plays a crucial role in the etiopathogenesis of skin diseases. There are many different types of skin-related autoimmune disorders including scleroderma, psoriasis, dermatomyositis, and autoimmune bullous disorders (11-13).

The presence of autoimmune antibodies not only attracts the attention of gynecologists due to adverse pregnancy outcomes, but also the dermatologists for the maintenance of healthy skin. In this study, we aimed to search the association of BV and skin disorders in patients with AAP.

\section{Material and Method}

We included 80 patients with AAP (anti-parietal antibody (APA), anti-nuclear antibody (ANA), or anti-smooth muscle antibody (ASMA) positivity in serum) in this retrospective cohort. The clinical and demographic characteristics of the patients were recorded.

All patients were evaluated for the presence of $\mathrm{BV}$ and 
skin disorders. Cervicovaginal smears were performed for the definitive diagnosis of BV. The cytological evaluation was performed through the Papanicolaou method. Fixed slides were first immersed in decreasing concentrations of alcohol solutions, then washed in distilled water. Rehydrated slides were then stained with Harris' Hematoxylin (Merck, Germany) and washed with tap water. $1 \%$ hydrochloric acid-alcohol (v/v) was used for decoloring. The slides were then immersed in a series of solutions containing increasing alcohol concentrations and were stained with Orange G (Merck, Germany) and EA 65 (Merck, Germany). To clean out the excess dye, slides were washed with $95 \%$ ethanol after each step. Stained smears were immersed in Xylene (Merck, Germany), then Entellan (Merck, Germany) a mounting medium and were covered with coverslips. Cytological findings were assessed on a light microscope and photographed (Leica DM 400B).

Skin disorders were grouped as acneiform disease, pruritus/xerosis cutis, psoriasis, skin tags, urticaria/dermatitis, fungal disorders, and viral diseases.

Statistical analyses were performed using the Statistical Package for the Social Sciences (SPSS, version 23). Groups were compared using the Fischer's Exact Test. p-values $<0.05$ were considered as statistically significant. The study was approved by the Hacettepe University Institutional Review Board with reference number GO 19/1064. The study was performed according to the Declaration of Helsinki.

\section{Results}

This retrospective study included 80 patients with serum AAP including anti-smooth muscle antibodies (ASMA), antiparietal antibody (APA), and anti-nuclear antibody (ANA). The rates of autoantibody positivities were given in table I. ANA was the most frequent positive autoantibody with a rate of $57.5 \%$.

Table I: Types of autoimmune antibodies, frequencies, and percentages.

\begin{tabular}{lcc}
\hline Autoantibodies & Frequency & Percentage \\
\hline ANA & 46 & 57.5 \\
ANA + APA & 17 & 21.3 \\
ANA + ASMA & 1 & 1.3 \\
APA & 14 & 17.5 \\
ASMA & 2 & 2.5 \\
Total & 80 & 100.0 \\
\hline
\end{tabular}

ANA: Anti-nuclear antibody, APA: Anti-parietal antibody, ASMA: Antismooth muscle antibody

Eleven of $80(13.75 \%)$ patients included in the study had various skin disorders including viral diseases, psoriasis, urticaria or dermatitis, telogen effluvium, acneiform disease, and skin tags. The most frequent skin disorder was a skin tag in this cohort $(36.3 \%, n=4 / 11)$. (Table II).
Table II: Types of skin diseases in our patient cohort

\begin{tabular}{lll}
\hline Types of skin diseases & BV (-) & BV (+) \\
\hline Negative & $59(85.5)$ & $10(90.9)$ \\
Viral diseases & $1(1.4)$ & $0(0.0)$ \\
Psoriasis vulgaris & $1(1.4)$ & $0(0.0)$ \\
Urticaria or dermatitis & $1(1.4)$ & $0(0.0)$ \\
Urticaria or dermatitis+Viral diseases & $0(0.0)$ & $1(9.1)$ \\
Telogen effluvium & $1(1.4)$ & $0(0.0)$ \\
Acneiform diseases+Viral diseases & $1(1.4)$ & $0(0.0)$ \\
Skin tag & $4(6.1)$ & $0(0.0)$ \\
Vitiligo & $1(1.4)$ & $0(0.0)$ \\
Total & $69(100)$ & $11(100)$ \\
\hline
\end{tabular}

The cervicovaginal smear slides which involved clue cells covered by adherent bacteria, a lack of Lactobacilli and neutrophil leukocytes, and an increased number of free cocci were detected (Figure 1), were diagnosed as BV $(n=11)$.

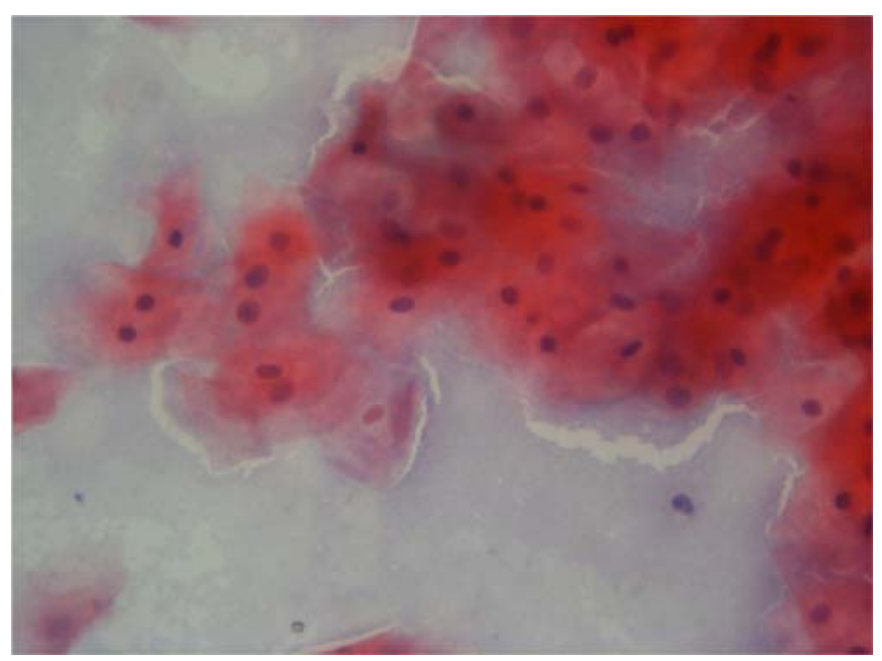

Figure 1: An example of a PAP-smear. Clue cells covered by bacteria, together with a lack of Lactobacilli and a dirty background can be seen (PAP-stain, x400).

When we evaluated the association of skin disorders with BV, only 1 (9.1\%) patient had BV and a skin disorder concomitantly. There was no statistically significant relationship between the presence of $\mathrm{BV}$ and skin disorders $(p>0.05)$ (Table III).

Table III: Cross-tabulation of the presence of skin disease and Bacterial vaginosis

\begin{tabular}{lccc}
\hline & \multicolumn{3}{c}{ Bacterial vaginosis } \\
\cline { 2 - 4 } & $(-)$ & $(+)$ & $p$ \\
\hline Skin disease $(-)(n=69)$ & $59(85.5)$ & $10(90.9)$ & 0.531 \\
Skin disease $(+)(n=11)$ & $10(14.5)$ & $1(9.1)$ & \\
Total & $69(100)$ & $11(100)$ \\
\hline
\end{tabular}

Fischer's Exact Test, $p>0.05$.

\section{Discussion}

Bacterial vaginosis is characterized by a reduction of 
Lactobacilli and an overgrowth of other commensal microorganisms in the vagina (14). This causes an imbalance of the vaginal microflora leading various gynecological complaints including fishy odor, thin, milky discharge, pruritus, irritation, and abdominal pain (15). BV also leads to skin manifestations, such as desquamation of the vulvar skin (7). However, BV may be asymptomatic in $50 \%$ of women and may be a cause of unfavorable pregnancy outcomes (16).

Autoantibodies are defined as antibodies resulting from immune system discrepancies caused by a failure to distinguish "self" from "non-self", thus targeting self-cellular components (17). Autoantibodies lead to placental inflammation and are associated with adverse pregnancy outcomes such as fetal growth retardation, miscarriage, and stillbirth (18). BV was found to be more frequent in patients with AAP in our previous study (6).

Autoimmune antibodies affect a variety of tissues and organs. The skin is one of the tissues which are commonly affected by autoimmune disorders (17). There are several different types of skin-related autoimmune disorders including scleroderma, psoriasis, dermatomyositis, and autoimmune bullous disorders (11-13). The incidence and severity of autoimmune skin diseases may vary depending on the type of skin disorders, gender, age, and ethnicity $(19,20)$.

In a study where the prevalence of common skin diseases in the European population (Germany, Italy, the Netherlands, Portugal, and Sweden) were evaluated in 12.377 participants, the most common skin diseases were warts (41.3\%), acneiform diseases (19.2\%) and contact dermatitis (15.0\%) (21). In our study, we found 11 of $80(13.75 \%)$ patients to have various skin disorders including viral diseases, psoriasis, urticaria or dermatitis, telogen effluvium, acneiform diseases, and skin tag. The most frequent skin disorder was a skin tag in our cohort $(36.3 \%, n=4 / 11)$.

We found that only $1(9.1 \%)$ of patients in our cohort to have both BV and skin diseases. This patient was diagnosed with chronic urticaria, as well as genital verrucae. We found no statistically significant relationship between the presence of BV and skin disorders.

The main limitations of this study are the inclusion of a relatively low number of cases and its retrospective design. The lack of information explaining the results of this study is another limitation. To the best of our knowledge, this is the first study to investigate the association of BV and skin disorders.

In conclusion, although autoimmune antibodies are important in the occurrence of skin problems, we found no association between the presence of skin disease and BV in AAP patients. Further studies including larger cohorts are warranted to confirm these results.
Acknowledgment: None

Funding: None

Conflict of Interest: Authors declared that there is no conflict of interest

Author contributions: BB: Study concept and design, manuscript writing and editing. HGD: Experiments, statistical analysis, literature search, and manuscript writing.

\section{References}

1. Bitew A, Abebaw Y, Bekele D, Mihret A. Prevalence of Bacterial Vaginosis and Associated Risk Factors among Women Complaining of Genital Tract Infection. Int J Microbiol. 2017;2017:4919404. doi: 10.1155/2017/491 9404.

2. Haltas H, Bayrak R, Yenidunya S. To determine of the prevalence of Bacterial Vaginosis, Candida sp, mixed infections (Bacterial Vaginosis + Candida sp), Trichomonas Vaginalis, Actinomyces sp in Turkish women from Ankara, Turkey. Ginekol Pol. 2012;83(10):744-8. PMID: 23383559 .

3. Bautista CT, Wurapa E, Sateren WB, Morris S, Hollingsworth B, Sanchez JL. Bacterial vaginosis: a synthesis of the literature on etiology, prevalence, risk factors, and relationship with chlamydia and gonorrhea infections. Mil Med Res. 2016;3:4. doi: 10.1186/s40779-016-0074-5.

4. Isik G, Demirezen Ş, Dönmez H, Beksaç M. Bacterial vaginosis in association with spontaneous abortion and recurrent pregnancy losses. J Cytol. 2016;33(3):135. doi: 10.4103/0970-9371.188050.

5. Georgijević A, Cjukić-Ivancević S, Bujko M. Bacterial vaginosis. Epidemiology and risk factors. Srp Arh Celok Lek. 2000;128(1-2):29-33. PMID: 10916461.

6. Donmez HG, Cagan M, Fadiloglu E, Unal C, Onder SC, Beksac MS. Is Bacterial Vaginosis Associated with Autoimmune Antibody Positivity? Cytopathology. 2020;31(4):298-302. doi: 10.1111/cyt.12846.

7. Bilardi JE, Walker S, Temple-Smith M, McNair R, Mooney-Somers J, Bellhouse C, et al. The burden of bacterial vaginosis: Women's experience of the physical, emotional, sexual and social impact of living with recurrent bacterial vaginosis. PLoS One. 2013;8(9):e74378. doi: 10.1371/journal.pone.0074378.

8. Hu Y, Zhu Y, Lian N, Chen M, Bartke A, Yuan R. Metabolic Syndrome and Skin Diseases. Vol. 10, Frontiers in Endocrinology. Frontiers Media S.A.; 2019. p. 788 .

9. Biga LM, Dawson S, Harwell A, Hopkins R, Kaufmann J, LeMaster M, et al. In: Anatomy and Physiology, 1st Ed. OpenStax/Oregon State University; 2020.

10. Anderson RT, Rajagopalan R. Effects of allergic dermatosis on health-related quality of life. Curr Allergy Asthma Rep. 2001;1(4):309-15. doi: 10.1007/s11882-001-0041-3.

11. Sadik CD, Schmidt E. Resolution in bullous pemphigoid. 
Vol. 41, Seminars in Immunopathology. Springer; 2019. p. 645-54.

12. Tseng CC, Chang SJ, Tsai WC, Ou TT, Wu CC, Sung WY, et al. Sex differential association of dermatomyositis with Sjögren syndrome. CMAJ. 2017;189(5): E187-93. doi: 10.1503/cmaj.160783.

13. McCormick T, Ayala-Fontanez N, Soler D. Current knowledge on psoriasis and autoimmune diseases. Psoriasis Targets Ther. 2016;6:7-32. doi: 10.2147/PTT. S64950.

14. Falagas ME, Betsi GI, Athanasiou S. Probiotics for the treatment of women with bacterial vaginosis. Vol. 13, Clinical Microbiology and Infection. Blackwell Publishing Ltd; 2007. p. 657-64.

15. Hay PE. Bacterial Vaginosis as a Mixed Infection. In: Brogden KA, Guthmiller JM, editors. Polymicrobial Diseases. Washington (DC): ASM Press; 2002.

16. Joyisa N, Moodley D, Nkosi T, Talakgale R, Sebitloane M, Naidoo M, et al. Asymptomatic Bacterial Vaginosis in Pregnancy and Missed Opportunities for Treatment:A Cross - Sectional Observational Study. Infect Dis Obstet Gynecol. 2019;2019:7808179. doi: 10.1155/2019/780 8179.
17. Janeway CA Jr, Travers $P$, Walport $M$, et al. Immunobiology: The Immune System in Health and Disease. 5th edition. New York: Garland Science; 2001.

18. Tanacan A, Beksac MS, Orgul G, Duru S, Sener B, Karaagaoglu E. Impact of extractable nuclear antigen, anti-double stranded DNA, antiphospholipid antibody, and anticardiolipin antibody positivity on obstetrical complications and pregnancy outcomes. Hum Antibodies. 2019;27(2):135-41. doi: 10.3233/HAB-180359.

19. Madu PN, Williams VL, Noe MH, Omech BG, Kovarik CL, Wanat KA. Autoimmune skin disease among dermatology outpatients in Botswana: a retrospective review. Int J Dermatol. 2019;58(1):50-3. doi: 10.1111/ijd.14201.

20. Rzany B., Weller N. Epidemiology of Autoimmune Skin Disorders. In: Hertl M. (eds) Autoimmune Diseases of the Skin. Vienna; Springer. 2001.

21. Svensson A, Ofenloch RF, Bruze M, Naldi L, Cazzaniga $\mathrm{S}$, Elsner P, et al. Prevalence of skin disease in a population-based sample of adults from five European countries. Br J Dermatol. 2018;178(5):1111-8. doi: 10.1111/bjd. 16248.

22. Brianti P, De Flammineis E, Mercuri SR. Review of HPVrelated diseases and cancers. Vol. 40, New Microbiologica. Luigi Ponzio e figlio Editori; 2017. p. 80-5. 